\title{
A PERTINÊNCIA DO MÉTODO EVANGELIZADOR DE JOSÉ DE ACOSTA PARA OS DIAS ATUAIS
}

\author{
THE RELEVANCE OF tHE EVANGELIZER METHOD \\ OF JOSE DA COSTA FOR THE PRESENT DAYS
}

\section{Roberto Hofmeister Pich* Tiago de Fraga Gomes**}

\section{RESUMO}

Para Acosta a fé explícita em Cristo é condição necessária para a salvação. No confronto de narrativas é preciso convencer. A religião como sistema simbólico de crenças e práticas situa-se dentro de uma cultura, sendo a educação metódica, empenhada, paciente e perseverante, algo determinante na formação dos costumes cristãos, na gradualidade.

Palavras-chave: Cultura. Cristo. Educação. Fé. Método.

\section{ABSTRACT}

For Acosta explicit faith in Christ is a necessary condition for salvation. In the narrative of confrontation is to convince. Religion as symbolic system of beliefs and practices is located within a culture, and the methodical education, committed, patient and persevering, something crucial in the formation of Christian customs, the gradualness.

Keywords: Culture. Christ. Education. Faith. Method.

\footnotetext{
* Professor do Programa de Pós-Graduação em Filosofia e do Programa de Pós-Graduação em Teologia da PUCRS, Porto Alegre. E-mail: <roberto.pich@pucrs.br>.

***Metre em Teologia pela PUCRS.
}

\begin{tabular}{|l|l|l|l|l|l|}
\hline Teocomunicação & Porto Alegre & v. 45 & n. 2 & p. 219-239 & maio-ago. 2015 \\
\hline
\end{tabular}




\section{Introdução}

José de Acosta foi um jesuíta espanhol nascido em Medina del Campo no ano de 1540 e falecido em Valladolid no ano de 1600. Foi como missionário para o Peru em 1571 e regressou à Espanha em 1587. Entre suas obras, merecem destaque De Procuranda Indorum Salute (1576) e Historia Natural y Moral de las Indias (1590). No presente trabalho, vamos abordar o método evangelizador de Acosta a partir da primeira obra referida, que trata sobre o tema da evangelização, fazendo transparecer a sua teologia da missão.

A obra De procuranda indorum salute, que ora nos propomos estudar, é a que melhor caracteriza sua preocupação com a evangelização dos índios. Está dividida em seis livros, cada um enfocando um tema específico. Esta obra é resultado de toda a experiência civil e religiosa de Acosta, desde as peregrinações por terras peruanas até o apostolado direto com os índios. As fontes inspiradoras de sua reflexão missionária são a doutrina dos Santos Padres e as Sagradas Escrituras. Acosta aplicou os critérios bíblicos, morais e filosóficos para refletir sobre a história da catequização desde a conquista até os seus dias. ${ }^{1}$

Entre 1582 e 1583 ocorreu o III Concílio de Lima, ${ }^{2}$ no Peru, convocado pelo Arcebispo Toribio Alfonso de Mogrovejo, como o objetivo de elaborar um catecismo em conformidade com as disposições do Concílio de Trento (1545-1563) e um manual para pregadores, em atenção à evangelização dos indígenas. Acosta teve participação intensa nesse concílio no que diz respeito a práticas e textos de catequese sobre educação cristã. Lima era o maior centro de orientação eclesiástica da América do Sul nesse período.

1 CARMO, José Vicente do. A proposta de evangelização de José de Acosta, p. 87-88.

2 "O III Concílio Limense (1582-1583) foi convocado pelo arcebispo do Peru, Santo Toríbio de Mogrovejo, em 15 de agosto de 1582. Acosta participou desse concílio como teólogo consultor, interventor, secretário, redator e, posteriormente, como defensor das teses conciliares diante do rei Felipe II e do papa Sixto V. O concílio propôs a edição de catecismos, confessionários e sermonários. Acosta ajudou na redação dessas proposições e foi o autor do texto em espanhol do catecismo maior, menor e da cartilha doutrinária. Quando Acosta solicitou o retorno à Espanha, ao geral da Companhia de Jesus, alegando problemas de saúde, recebeu do bispo de Lima, Mogrovejo, a missão de também defender os decretos conciliares na Europa." (Ibid., p. 82). 
Algumas questões são fundamentais para compreender o método de Acosta: O que é o conhecimento de Cristo e quando ele acontece? O que é necessário de conhecimento de Cristo para que o ser humano seja salvo? Como Cristo pode ser um Cristo para todos? A obra de Acosta pode ser um exemplo das discussões cristológicas pós-tridentinas típicas da Universidade de Salamanca. Acosta defenderá a ideia que para a salvação é necessário a fé, mas não somente isso, é preciso uma fé explícita em Cristo. A fé é uma condição necessária, e precisa ser declaradamente cristã. A salvação requer a fé explícita.

A proposta de catequese/evangelização de Acosta girava em torno de alguns eixos fundamentais. Destacamos três, que sempre figuram, direta ou indiretamente, em seus textos. O primeiro deles é a perspectiva de promover o índio à civilização. O segundo é a tutela. $\mathrm{O}$ índio precisa ser tutelado para ser promovido à civilização e ao cristianismo. O método era o de manter constante vigilância sobre os comportamentos indígenas. E o terceiro é a confissão, que figurava como um espaço onde se controlava e se reprimia a religiosidade indígena. A ruptura com a religião e cultura indígena acontecia de forma controlada. O confessionário era o lugar de controlar as 'superstições' e 'idolatrias' indígenas. Na visão de Acosta, as manifestações religiosas dos índios eram inspiradas pela força demoníaca. Deviam ser abandonadas. Somente assim aceitariam Jesus Cristo e a salvação. ${ }^{3}$

A premissa de Acosta parte do universalismo evangélico. "Não há raça alguma de homens que esteja excluída da pregação do Evangelho e da fé". ${ }^{4}$ É nítido que para Acosta há uma verdade e é preciso que todos a sigam. Todos devem escutá-la, sendo que a Igreja é o veículo dessa mensagem salutar, cujo centro é Jesus Cristo. Todos os povos precisam ser ensinados a respeito da verdade absoluta, que se traduz na fé cristã.

O mandato missionário é universal e ninguém está excluído dele, nem poderá menosprezá-lo. "Quem se atreverá, portanto, a menosprezar um preceito tão insigne e tantas vezes encomendado"? 5 Todo povo, toda raça e toda língua são destinatários do misterioso desígnio salvador de

\footnotetext{
3 Ibid., p. 178-179.

4 ACOSTA, José de. De procuranda indorum salute, v. 23, p. 75.

5 Ibid., p. 77.
} 
Deus. Inclusive os homens do Novo Mundo "hão de ser chamados e conduzidos ao conhecimento do nome e glória de Cristo". ${ }^{6}$ Deus não faz distinção entre povos, mas chama a todos indistintamente.

\section{Algumas premissas do método de José de Acosta}

\subsection{Crítica ao método pacifista e voluntarista de Bartolomeu de Las Casas}

Bartolomeu de Las Casas era adepto dos meios pacíficos para o anúncio do Evangelho, mas nem por isso deixou de lançar sua voz profética contra a opressão dos índios, defendendo os seus direitos, pois "sem justiça não existe paz autêntica. [...] Tratava-se de desmascarar um pretenso uso da força para evangelizar, fazendo perceber que a guerra era empreendida apenas pela cobiça do ouro". ${ }^{7} \mathrm{Na}$ mesma linha, a princípio, situa-se o pensamento de Francisco de Vitória, para o qual crer é um ato voluntário, sendo o temor um fator que afeta negativamente a vontade do indivíduo. No entanto, quando trata dos títulos legítimos, Vitória defende a ideia de que os espanhóis têm o direito de anunciar o Evangelho sem qualquer impedimento, alegando que "criar obstáculos para este anúncio se converte em uma injúria ao direito dos cristãos a proclamar sua mensagem". ${ }^{8}$ Não se pode forçar a conversão, mas é lícito eliminar os impedimentos à obra da evangelização. Apesar de não usar o mesmo tom de submissão utilizado por João Ginés de Sepúlveda, Vitória corre o perigo de ser mal compreendido. Las Casas toma outra postura, pois não quer correr o risco de eliminar a liberdade do ato de fé.

Com seu método evangélico, Las Casas pretende responder a seguinte pergunta: como o anúncio da religião cristã deve chegar a quem antes nunca o tinha ouvido? Para isso, é preciso convencer pelo único modo de evangelizar: "os meios pacíficos, vale dizer, a persuasão e o diálogo", 9 sem o uso da força, pois é preciso ultrapassar muitos bloqueios intelectuais e espirituais para que a mensagem do Evangelho seja acolhida por aqueles aos quais ela é ainda uma novidade e que até então nunca teve alguma importância. Não se trata de conhecimento,

\footnotetext{
6 Ibid., p. 79-80.

7 GUTIÉRREZ, Gustavo. Em busca dos pobres de Jesus Cristo, p. 131.

8 Ibid., p. 158.

9 Ibid., p. 191.
} 
mas de importância. É preciso se questionar: quais os principais conflitos e obstáculos para que a pregação da mensagem cristã tenha sucesso? Las Casas tem a explícita preocupação que a recepção da Boa Nova seja voluntária, sincera e espontânea.

Por isso, "o modo de encaminhar os homens à verdadeira religião precisa ser delicado, doce e suave, persuasivo para o entendimento e atrativo para a vontade", ${ }^{10}$ pois a fé implica assentimento da inteligência ao que se crê, pois o crente é um ser pensante que necessita de razões que o convençam. E em virtude do livre-arbítrio, a vontade precisa ser atraída para se inclinar a determinado fim, pois "a vontade determina o intelecto, porque considera digno, convincente e bom aderir a isso e assentir a essa opção". ${ }^{11}$ É nesse sentido que é preciso persuadir o entendimento e atrair a vontade.

Las Casas combate uma cultura de evangelização superficial e coativa. Visivelmente Las Casas quer dizer aos seus contemporâneos como indivíduos realmente aderem a novas convicções. Las Casas combate a relação entre colonização e catequese. Ele está interessado na espontaneidade na adoção de convicções, diante de um modelo cultural de cristandade. Como que genuinamente a religião vai entrar na cosmovisão dos indivíduos? O método evangélico deve levar isso em consideração. Como seres humanos ganham convicções? Há muitas maneiras: por testemunho ou por explicações de teoremas, por exemplo. No caso da mensagem cristã há elementos complicadores, pois ela diz respeito a conteúdos não evidentes. Las Casas quer evitar convicções não sinceras. Nesse sentido, Acosta vai dizer que a missão católica foi um fracasso nesse sentido, porque superficial, induzindo as pessoas ao falso juramento, ao falso testemunho e à idolatria. No início do séc. XVII a preocupação da teologia católica na América Latina é a idolatria. Daqui parte a crítica de Acosta ao método evangelizador de Las Casas: é preciso ser mais realista e partir de uma boa catequese para tornar Cristo explicitamente conhecido.

\subsection{Desejo de evitar o escândalo da idolatria}

Para Acosta o batismo só pode ser administrado àqueles que professam integralmente a fé em Cristo, expressa no símbolo da fé,

\footnotetext{
${ }^{10}$ LAS CASAS, Bartolomeu de. Único modo de atrair todos os povos à verdadeira religião, p. 61 .

11 Ibid., p. 68.
} 
para que seja evitado o escândalo da idolatria. A teologia da missão de Acosta é a primeira teologia do séc. XVI que não tem a ênfase na persuasão, mas no ensino, na catequese, pois a sua preocupação está na falsidade na confissão de fé. A tese de Costa é que sem o conhecimento explícito de Cristo em forma de confissão, Cristo não se realiza no indivíduo. Isso é um elemento incontornável em Acosta. Cristo é necessário para a salvação, o que não significa que o conhecimento de Cristo seja absolutamente necessário no caso de ignorância invencível, como é ocorre com aqueles que nunca ouviram falar de Cristo. Essa discussão acontece em Salamanca e leva em consideração as condições do indivíduo.

Em De procuranda indorum salute Acosta fez sua radiografia da conquista, catequização e colonização dos índios. Denunciou as violências das guerras contra os indígenas, a exploração do seu trabalho nas encomendas e os erros pastorais, tais como: o desconhecimento da língua indígena e a falta de ética dos colonizadores. Ele buscou desvendar as causas desses problemas e apontar uma saída para superar a crise da evangelização dos índios no Peru. Muitos já haviam recebido o Evangelho. O fato do Evangelho vir associado à violência das guerras e à exploração do trabalho, segundo Acosta, não os levou a uma verdadeira conversão. Essas causas determinavam o estágio da catequese, deixando os índios sem o conhecimento de Jesus Cristo. Sua proposta catequética destinava-se, especificamente, aos Incas, mas poderia servir também aos diferentes povos indígenas da América. Na sua visão, era importante haver uma metodologia catequética para que os índios se convertessem à fé cristã. ${ }^{12}$

A primeira geração de missionários no Novo Mundo, representada por Francisco de Vitória, protagonizou o batismo em massa. A segunda geração, tendo como expoente Bartolomeu de Las Casas, foi mais pacifista e voluntarista. Já a terceira geração, contemporânea a Jose de Acosta, se questiona: como discernir que alguém se torna de fato um convertido? A religião é algo profundo, envolve arquétipos simbólicos profundos na psicologia social de um povo. Acosta não quer conversões superficiais, quer evitar a idolatria. Conversões forçadas geram

${ }^{12}$ CARMO, José Vicente do. op. cit., p. 95. 
escândalo. Não pode haver fé sem vontade. Dizer a Deus o que não se acredita é escandaloso. ${ }^{13}$

Os apóstolos de Cristo pregaram o Evangelho e batizaram em nações cujos costumes não eram os mais elevados do ponto de vista ético e religioso, porém, não fizeram diferença entre gregos e bárbaros ou entre sábios e ignorantes. Entendiam que pelo conhecimento dos mistérios de Deus é gerada uma nova criatura renovada à imagem de seu Criador. É preciso confiar na fidelidade de Deus que estabelece as suas promessas, não excluindo da salvação nenhuma raça de mortais. "Deus, nosso Salvador, quer que todos os homens sejam salvos e cheguem ao conhecimento da verdade. Pois há um só Deus, e um só mediador entre Deus e os homens, um homem, Cristo Jesus, que se deu em resgate por todos". (1 Tm 2,3-6). Essa certeza faz Acosta sistematizar todo o seu plano de evangelização em torno da necessidade do conhecimento explícito de Cristo por parte de todos os povos, incluindo os índios do Novo Mundo. Esse universalismo da salvação vai mover Acosta a fundamentar com sua teologia que é preciso buscar, através da missão, a salvação das almas.

A partir da teologia de Acosta, podemos nos perguntar: como acontece a evangelização? Para Acosta acontece quando Cristo é confessado por aqueles que ainda não o conheciam. ${ }^{14}$ Acosta faz uma interpretação cristológica das narrativas históricas. O papel da Igreja faz mostrar a todos os povos Cristo como o cerne de sua história, pois todas as histórias convergem para Cristo. Por isso, é preciso que Cristo seja entendido em todas as histórias para que estas se unifiquem em Cristo. Esta é a convicção de Acosta e dos missionários do séc. XVI.

\footnotetext{
13 “A conquista da América fora legitimada pelas bulas de Alexandre VI e Júlio II. Ambas privilegiavam os reis católicos, concedendo-lhes territórios em troca de obrigações de ordem espiritual, como o envio de missionários e construção de igrejas. A Coroa tinha o domínio dos povos indígenas, mas também o dever de submeter esses povos à fé católica. O direito patronal deu aos reis espanhóis e a seus representantes o poder de dirigir e organizar a estrutura da Igreja na América. Acosta questionava como duas coisas tão diferentes entre si - Evangelho e guerra - puderam estar entrelaçadas na conquista da América, considerando que a fé é ato livre." (Ibid., p. 96-97).

${ }^{14}$ Não podemos abandonar o cerne da narrativa cristã ao ponto de secularizá-la. Esvaziando o proprium, perde-se a Boa Nova da mensagem cristã. Nosso tempo tem uma resistência a narrativas com pretensões universalistas. Vivemos um niilismo depressivo, pós-revoluções contra-repressivas.
} 
Há uma atmosfera de frustração nos missionários na época em que Acosta escreve a sua obra. ${ }^{15}$ Acosta quer animar a evangelização questionando: será que os indígenas devem fazer parte deste plano histórico-salvífico? Será que a evangelização faz sentido? Acosta quer reanimar os missionários.

Todos são chamados ao Evangelho. Essa era a consciência que devia mover, inicialmente, os agentes missionários para superar o pessimismo. Além disso, Deus mesmo é quem dá a salvação. Somente a nível pessoal pode haver a rejeição da graça divina. Embora sendo um trabalho difícil e árduo, a catequização dos índios era possível. A missão é por natureza universal e responde ao mandato de Jesus. Os missionários precisam assumir a missão de levar os índios à conversão, vencendo a concepção corrente de que eles não tinham inteligência e capacidade suficientes para receber a doutrina da salvação e notar que a catequização constante muda lentamente os costumes. ${ }^{16}$

A ênfase do método missionário de Acosta centra-se na catequese para tornar Cristo explicitamente conhecido. Acosta é um realista, pois acredita que não se acredita naquilo que não se conhece. Não podemos subestimar o devido equilíbrio entre pregação (ensino), autoridade e exemplo. Isso fundamenta a sua teologia da missão.

\subsection{Necessidade de um processo pedagógico para a educação na fé}

Para Acosta, os indígenas precisam passar por uma extensa, ampla e detalhada pedagogia para que a evangelização dê resultados, pois não estão prontos para o Evangelho. Essa pedagogia exige autoridade, força. No confronto de narrativas, de visões de mundo, é preciso convencer. Sem força e autoridade, a Igreja não irá vencer a incredulidade, para que se chegue a uma fé explícita. A religião como conjunto de estruturas simbólicas e atitudes correspondentes tem para os indivíduos uma

\footnotetext{
15 "As estruturas do padroado e da encomenda prejudicaram a catequese dos índios enquanto carregavam consigo o contra-testemunho. Acosta pretendia resgatar a esperança dos evangelizadores na salvação dos índios. Também as dificuldades geográficas, a desconfiança em relação à salvação dos índios, a precariedade do método e do conteúdo da fé, provocavam nos evangelizadores o pessimismo. Faltava-lhes uma pedagogia simples e adequada para transmitir a fé aos indígenas.” (Ibid., p. 111-112).

${ }^{16}$ Ibid., p. 113-114.
} 
dimensão profunda inimaginável. No entanto, para Acosta, sem algum tipo de força, as pessoas não acreditam naquilo que não é evidente, como é o caso da fé. O testemunho de autoridade é diferente da imposição. É uma força disciplinar para convencer a respeito do que não é evidente. Para Acosta é necessária certa severidade para adotar a vontade de Deus. É preciso educar para convencer a respeito da mensagem cristã. Toda severidade, porém, não deve prescindir do amor. "O amor restabelece facilmente o que o rigor disciplinar havia perturbado". ${ }^{17}$ Uma coação conveniente..$^{18} \mathrm{O}$ princípio de autoridade está presente na crença religiosa.

É preciso educar para a fé. Acosta não é um defensor da guerra de conquista, ${ }^{19}$ pois o anúncio do Evangelho pela violência é inadequado e contraditório, mas sendo um realista, Acosta possui a convicção de que os indígenas precisam ser preparados para confessar a fé em Cristo. É uma concepção antropológica de religião. A religião para Acosta é um sistema simbólico de crenças e práticas situado dentro de uma cultura, e a educação é determinante na formação dos costumes. "O se faz por costume não causa dor, mas prazer; A força do costume é como uma segunda natureza". ${ }^{20}$ Acosta fala e pensa em religião como sistema de hábitos, costumes e esquemas mentais. A religião cristã precisa estar tão dentro do indivíduo, que se torne uma inclinação ou disposição natural. $\mathrm{Na}$ elaboração de seu método, Acosta chega a uma conclusão de que substituir uma visão de mundo é algo mais complicado do que pensava Bartolomeu de Las Casas. A religião cristã só se tornará possível com a educação e a transformação dos costumes.

Não existem duas humanidades, existe humanidade má formada e humanidade bem formada. $\mathrm{O}$ mandato é universal porque todos os seres humanos são capazes de compreender e viver a mensagem cristã.

17 ACOSTA, José de. op. cit., p. 149.

18 "Na América, a fé, ato livre e dom de Deus, chegara como fruto da guerra. Os índios eram considerados bárbaros e deveriam ser 'civilizados', mas não se justificavam as violências e as guerras. A condição dos índios exigiria, simplesmente, o uso de uma força moderada, que não prejudicaria os povos e bens indígenas em si." (CARMO, José Vicente do. op. cit., p. 98).

19 "As guerras contra os índios, normalmente, foram justificadas com a visão de que eles eram infiéis. Acosta negou esses argumentos justificantes. A licitude das guerras não podia estar na infidelidade dos índios, ainda que contumaz, nem nos seus crimes contra a natureza, nem mesmo, na defesa dos índios inocentes frente aos seus próprios tiranos." (Id. Ibid., p. 99-100). Para Acosta, a chamada "guerra justa" era na realidade usurpação de poder, pois o real interesse era apenas expandir o domínio, sendo que a prioridade não era a conversão dos índios, e sim, os interesses do reinado.

20 ACOSTA, José de. op. cit., p. 151. 
É preciso que os seres humanos sejam revestidos pouco a pouco por novas inclinações. "É assunto muito difícil desarraigar inclinações naturais e costumes inveterados e transformá-los em hábitos novos". ${ }^{21}$ Moldar os costumes exige paciência e perseverança. "Pouco a pouco os costumes vão se transformando para melhor". ${ }^{22}$ É próprio da fé cristã a gradualidade na sua acolhida e vivência. Mas também é preciso levar em consideração os sinais de humanismo e cristandade advindos das culturas bárbaras.

\section{Requisitos fundamentais da ação evangelizadora}

\subsection{Confiar na graça de Deus e não buscar os próprios interesses}

Muitos povos foram arrasados e miseravelmente arruinados por conta de uma violência cujo pretexto foi o de estender a religião de Cristo, sendo que na realidade o que se buscava eram os próprios interesses. "A causa de os índios não terem progredido na fé estava correlacionada com a violência das guerras e do processo de colonização". ${ }^{23}$ A caridade prudente que busca a salvação do próximo deve ser a mestra da evangelização. "Não há que fazer o mal para que resulte o bem". ${ }^{24}$ Não se faz guerra justa. A guerra de conquista é injustificável para propagar a fé. ${ }^{25}$

É preciso primeiramente confiar na graça de Deus, pois a fé e a conversão são dom de Deus. A oração deve preceder a ação na pregação do Evangelho e na catequese. O próprio Cristo rezava antes de uma

${ }^{21}$ Ibid., p. 155.

22 Ibid., p. 157.

${ }^{23}$ CARMO, José Vicente do. op. cit., p. 137.

${ }^{24}$ ACOSTA, José de. op. cit., p. 253.

25 "A península ibérica, no século XVI, buscava a expansão territorial e comercial. A Igreja tutela esse projeto enquanto confere à monarquia hispânica plenos poderes sobre as terras descobertas e as que futuramente adquirisse. Em troca, os reis deviam investir na conversão à fé cristã dos diversos povos dominados e submetidos pelo processo colonizador. À Igreja interessava também a expansão da fé cristã. Expansão imperialista e conversão dos povos conquistados à fé católica fazem parte da dominação colonial. A ideologia do sistema colonial se esclarece, pois o interesse dos espanhóis é o de anexar novas terras e novas riquezas no reino da Espanha. A cristandade colonial não reconhece o ser diferente como princípio de alteridade. Na raiz do pensamento colonialista já está a negação do desconhecido e do diferente. A palavra 'descobrimento' já introjeta um conceito negativo do outro. A 'conquista' do outro indica que o outro não é ainda uma nação ou povo, com autonomia, e a 'conquista' espiritual indica que o outro carece de religião." (CARMO, José Vicente do. op. cit., p. 196-197). 
ação importante. "O fiel ministro de Deus não tanto deve esperar o fruto de seu discurso e diligência, quanto de suas orações". ${ }^{26}$ A oração comunitária é mais eficaz que a solitária, e a oração de intercessão é de grande ajuda, pois entram na dinâmica da comunhão e da solidariedade divinas, superando uma espiritualidade egoísta e solipcista.

No âmbito da preparação espiritual do missionário, Acosta considerou como indispensável a oração [...] Para nosso autor, a oração era a fonte de inspiração e o meio de vencer o espírito arrogante e interesseiro. Fundamentava todo o cuidado apostólico. [...] A oração constante era vista como instrumento importante na conversão dos índios e não podia faltar na vida dos agentes missionários. ${ }^{27}$

A interioridade de vida e o bom exemplo falam mais claramente e persuadem melhor que os discursos. "O caminho mais seguro para atrair os homens ao Evangelho é a bondade e a generosidade". ${ }^{28}$ Não buscar benefícios e os próprios interesses, mas apenas o bem das pessoas, agindo com espírito apostólico. No entanto, na tarefa da evangelização é preciso buscar na Palavra de Deus a fonte do ensinamento, usando uma linguagem simples, compreensível e familiar, com comparações e expressões do cotidiano, fazendo uso de símbolos e cerimônias cúlticas que ilustrem mais pedagogicamente a fé. É imprescindível utilizar sermões públicos, cativando, estimulando, ameaçando e persuadindo, confiando mais na virtude de Cristo que na sabedoria humana.

Acosta afirma que os costumes dos índios que não vão contra o cristianismo se devem conservar. Onde não há oposição à mensagem cristã e sua justiça, não é preciso mudar. "Há que ir pouco a pouco imbuindo os índios nos costumes cristãos. E há que cortar passo a passo os ritos supersticiosos e sacrílegos e os hábitos de bárbara crueldade". ${ }^{29}$ A conversão dos costumes é um processo gradativo que exige paciência e compreensão por parte dos evangelizadores e catequistas. É necessária certa progressividade para moldar os costumes. Para Acosta, a religião é um sistema simbólico de convicções e atitudes. Sua preocupação é que

\footnotetext{
${ }^{26}$ ACOSTA, José de. op. cit., p. 265.

${ }^{27}$ CARMO, José Vicente do. op. cit., p. 139-140.

${ }^{28}$ ACOSTA, José de. op. cit., p. 267.

${ }^{29}$ Ibid., p. 587.
} 
não haja apenas uma forma exterior de confissão cristã e o conteúdo continue sendo inerente ao paganismo. Os jesuítas querem a alma das pessoas. Quando os costumes são nocivos, é preciso substituí-los por hábitos bons.

\subsection{Aprender o idioma e a cultura local para anunciar com eficácia}

E para que as missões junto aos índios surtam êxito, não há outro caminho que "com estudo e paciência ir-se impondo no idioma. É difícil e trabalhoso, mas não é impossível". ${ }^{30}$ A quem Deus inspira, capacitando com os dons necessários para a missão, move também à ação, animando e fortalecendo. Além disso, as línguas indígenas não são muito complexas, mas relativamente simples e fáceis de aprender, sendo elas particularmente concisas e expressivas.

Acosta entendeu que os missionários precisavam de uma melhor preparação intelectual. Nesse campo apontava a necessidade de que tivessem a ciência necessária, o conhecimento da língua indígena e prognosticava a urgência de se ter teólogos sábios para a América Espanhola. [...] Acosta aprendera a língua quéchua no contato pastoral. Com base na sua experiência, insistiu em que os missionários deviam conhecer a língua dos índios. $\mathrm{O}$ desconhecimento da língua indígena significava o desinteresse pela sua salvação, dado que a fé entra pelos ouvidos. Desconhecendo a língua, os missionários desconheciam automaticamente a cultura indígena. [...] O Evangelho, apesar de comunicado, não provocava virtudes cristãs na vida dos índios, porque não era compreendido por eles. A pregação constante e repetitiva fazia parte do método de evangelizar, contanto que fosse em sua língua. A experiência pastoral de Acosta demonstrou que eles ficavam atentos ao que os missionários lhes anunciavam em sua própria linguagem. [...] Acosta indicou o aprendizado das línguas mais comuns do Peru: quéchua e aymara. ${ }^{31}$

Muitas palavras espanholas a respeito de coisas desconhecidas até então para os índios, foram incorporadas ao seu idioma. E no que diz respeito à religião, nem sempre é possível traduzir satisfatoriamente $o$ vocabulário cristão para o idioma indígena. Poderia haver nesses casos

\footnotetext{
${ }^{30}$ ACOSTA, José de. De procuranda indorum salute, vol. 24, p. 71.

${ }^{31}$ CARMO, José Vicente do. op. cit., p. 143-146.
} 
uma apropriação dos vocábulos da fé em língua castelhana, mesmo que a dificuldade de pronunciação moleste aqueles que estão acostumados à suavidade da língua materna.

$\mathrm{O}$ uso e o exercício ajudam a superar essas dificuldades. O que serve de consolo é que a gramática da língua indígena não é complicada. As gramáticas e os exercícios são úteis para o aprendizado intelectual e acadêmico, porém, a realidade da prática da conversação com os índios torna familiar e fluente a língua. ${ }^{32}$ "Com audácia há que expor-se a errar para deixar de errar alguma vez". ${ }^{33}$ Dar lições é fácil, mais complicado é introduzir na prática. No entanto, a dificuldade mais terrível é a má vontade dos homens para se dedicarem ao aprendizado.

De acordo com Acosta, para bom proveito dos índios, os ministros do Evangelho precisam se dedicar a "aprender com todo entusiasmo a língua dos índios e a praticá-la depois de aprendê-la". ${ }^{34}$ Acosta louva a atitude dos dominicanos cujo método prevê que o primeiro ano de apostolado entre os nativos esteja inteiramente dedicado ao aprendizado do idioma local, para só posteriormente exercerem o seu trabalho apostólico. Na regra dos jesuítas está previsto "que todos falem a língua do lugar em que residem" 35 para que tenham a possibilidade de anunciar a Palavra de Deus oportunamente.

Caso não seja possível dedicar-se ao estudo da língua, Acosta recomenda que se recorra ao auxílio de um intérprete de confiança. $\mathrm{O}$ intérprete não precisa traduzir palavra por palavra, mas dizer o essencial da mensagem veiculada, pois os índios não têm necessidade de grandes discursos, mas de palavras fáceis e acomodadas à sua mentalidade.

\subsection{Sobre o ministro do Evangelho pesam grandes responsabilidades}

De acordo com Acosta, grande responsabilidade pesa sobre o ministério dos missionários evangelizadores. "O ministro de Deus há de

\footnotetext{
32 “Assinalando as dificuldades e os meios de superá-las, Acosta propôs um método popular de aprendizagem das línguas indígenas: a prática constante de conversações com os índios, ouvindo-os e falando-lhes, a fim de que o idioma se tornasse familiar aos missionários e, depois, pudessem pregar sem ter medo de errar." (Ibid., p. 148).

${ }_{33}$ ACOSTA, José de. op. cit., p. 77.

${ }^{34}$ Ibid., p. 79.

${ }^{35}$ Ibid., p. 79.
} 
ser mestre dos outros que recebeu a seu cuidado". ${ }^{36}$ Requer-se dele um conhecimento doutrinal profundo e bem elaborado, e uma capacidade pedagógica para ensinar e para rebater os adversários, assim como uma profunda vida de oração e de doação à causa do Evangelho. Qualidade na pregação, fruto de uma sólida formação intelectual e testemunho de vida, reflexo de uma clara convicção de fé, são requisitos básicos e imprescindíveis na vida do missionário evangelizador.

O missionário tornar-se-ia idôneo se se dedicasse à vida de oração, como fundamento do apostolado, ao desprendimento e zelo pastoral, aprendendo a língua e as tradições indígenas, conhecendo melhor a doutrina da Igreja e desenvolvendo a metodologia do anúncio do Evangelho. Sua proposta parte da necessidade da exemplaridade. A idoneidade do missionário dependeria de sua consciência ministerial e de sua formação, que respondessem à messe da América Espanhola. ${ }^{37}$

O missionário não fala em nome próprio, ele não é o proprietário da mensagem que transmite. "Quem fala em seu próprio nome busca seu próprio prestígio". ${ }^{38} \mathrm{O}$ amor de Cristo o faz não viver mais para si, pois o trabalho missionário junto aos indígenas é muito e proporciona pouco reconhecimento social. É preciso ter amor à causa do Evangelho, para expor de acordo com a capacidade dos ouvintes as verdades do credo e dos principais mistérios da fé, exortando a respeito dos mandamentos de Deus e dos sacramentos.

É desejável no ministro de Deus "uma exímia santidade de vida junto com iguais méritos de prudência e habilidade". ${ }^{39}$ Ajuda na sua formação a leitura dos Santos Padres e das Sagradas Escrituras. É oportuno ter um mínimo de cultura teológica e doutrinal. E a respeito dos ritos, costumes, superstições e modos de vida dos índios, só a convivência e a experiência podem transformar. $\mathrm{O}$ evangelizador precisa conhecer o seu povo, caminhar a sua frente. Isso exige tempo de permanência entre os que são confiados aos seus cuidados.

\footnotetext{
${ }^{36}$ Ibid., p. 83.

${ }^{37}$ CARMO, José Vicente do. op. cit., p. 138.

${ }^{38}$ ACOSTA, José de. op. cit., p. 85.

${ }^{39}$ Ibid., p. 87.
} 


\section{Peculiaridades do método de José de Acosta}

\subsection{Um método gnosiológico e cristocêntrico}

O método evangelizador de Acosta é gnosiológico e cristocêntrico. ${ }^{40}$ Para Acosta, é preciso refletir em torno do mistério de Cristo, pois "o fim da Lei é Cristo", ${ }^{41}$ o seu cumprimento perfeito, e toda Escritura é cristocentrada. A Igreja tem como missão fundamental anunciar a Cristo, pois sem o conhecimento de Cristo, não há salvação. "A vida eterna é um verdadeiro e perfeito conhecimento de Cristo". ${ }^{42}$ São dois os focos da doutrina cristã: conhecimento e amor a Cristo. São duas as tarefas de quem ensina o Evangelho: ensinar e exortar. "Cristo é o fim de todo o ensinamento e conhecimento; e a caridade é o fim de toda exortação e ação". ${ }^{43}$ Todo o conhecimento de Cristo, a fé, nos é transmitido no credo, e toda ação de caridade, no decálogo. ${ }^{44}$ "O próprio do pregador cristão é ensinar a fé e formar os costumes". ${ }^{45}$ Anunciar a Cristo aos povos: eis a tarefa fundamental do servidor do Evangelho. ${ }^{46}$

A teologia missionária sempre teve como ponto de partida $\mathrm{o}$ anúncio de Jesus Cristo. Naquela época, o embasamento estava na teologia tridentina. Jesus Cristo estava no centro de toda pregação missionária. Ele e a Igreja eram apresentados como o único

\footnotetext{
40 “Acosta considerou o método apostólico coerente com o Evangelho. Merecia particular atenção pelo fato de ter sido empregado por Cristo, os apóstolos e não ser violento. Esse método, entretanto, não poderia ser aplicado à totalidade dos povos indígenas. [...] A 'ferocidade' e a 'desumanidade' dos índios convertiam-se em argumentos para desaconselhar o método apostólico. A missão de evangelizar os índios era difícil, porém o martírio não seria o caminho para aliviar o fardo que pesava sobre cada missionário. [...] Outra dificuldade de adotar o método apostólico estava na própria vida dos missionários, que não tinham a fé e a capacidade necessárias para fazer milagres. [...] A proposta de Acosta acentuará a fé, a caridade e o testemunho de vida. [..] Adequar os costumes indígenas à fé e ter ética pastoral resultavam num método conveniente. Conformar os costumes indígenas à fé cristã era o 'milagre' mais fundamental, cuja missão era, principalmente, dos missionários.” (CARMO, José Vicente do. op. cit., p. 130-133).

${ }^{41}$ ACOSTA, José de. op. cit., p. 177.

${ }^{42}$ Ibid., p. 179.

${ }^{43}$ Ibid., p. 179.

44 "Crendo na Igreja, os índios deviam aprender os mandamentos, pois eles formavam os costumes. Para Acosta, os mandamentos revestiam-se desta importância. Graças a eles, poder-se-ia combater e desacraditar a 'idolatria' e os comportamentos indígenas contrários à lei cristã." (CARMO, José Vicente do. op. cit., p. 163).

${ }^{45}$ ACOSTA, José de. op. cit., p. 179.

46 "A proclamação do Evangelho é a primeira tarefa dos apóstolos e de seus sucessores." (ZILLES, Urbano. Religiões, p. 92).
} 
caminho de salvação. Os índios precisavam, mesmo não chegando a compreender os mistérios da fé, pelo menos crer nesses mistérios. [...] Acosta acreditava que a maneira de ensinar os mistérios da fé devia observar a capacidade dos índios, explicando-lhes a fé com simplicidade. Dessa forma, os índios compreenderiam os ensinamentos da fé, sem a necessidade de raciocínios difíceis. O importante era repeti-los com persistência para gravá-los no coração, prescindindo sempre da experiência dos indígenas. ${ }^{47}$

O núcleo fundamental de todo ensinamento evangélico é a pessoa de Cristo, sabedoria, justificação e redenção. A fé em Cristo é o fim da pregação cristã, mas não uma fé inoperante, mas uma "fé viva e eficaz e fecunda que obra a impulsos do amor". ${ }^{48}$ A maioria dos missionários anuncia a Cristo de maneira imprópria, sem despertar interesse nos interlocutores. "O dever primordial e mais importante do catequista do Evangelho há de ser este: que o neófito se atenha a Cristo e o compreenda com toda a memória e a inteligência e a mente de que seja capaz" ${ }^{49}$ Cristo foi anunciado nos profetas e na Lei antiga, e os primeiros pregadores do Evangelho não falaram de outra coisa que de Cristo, nosso mestre e redentor. "A salvação para todos os homens se concretiza em conhecer a Cristo". ${ }^{50} \mathrm{O}$ empenho fundamental do educador cristão deve ser ensinar a Cristo para que todos o conheçam.

Em sua metodologia missionária Acosta traçou perspectivas, procurando resgatar a autoridade dos missionários frente aos índios. Inspirava na simplicidade e no exemplo da prática pastoral de Francisco Xavier. [...] Nessa metodologia, Acosta destacava a importância de adaptar-se à capacidade de compreensão dos índios, que não era abstrata. O conteúdo da catequese devia ser transmitido por meio de conceitos indígenas. Os índios compreenderiam o conteúdo da fé cristã desde que a linguagem dos missionários fosse simples e refutasse a sua "idolatria". ${ }^{51}$

Para Acosta, é preciso conhecer a Cristo para se salvar. Acosta acha absurda a opinião de que alguns podem conseguir a salvação eterna sem conhecer a Cristo. Deus quer que todos se salvem, porém, a salvação não

\footnotetext{
${ }^{47}$ CARMO, José Vicente do. op. cit., p. 156-157.

48 ACOSTA, José de. op. cit., p. 181.

${ }^{49}$ Ibid., p. 183.

${ }^{50}$ Ibid., p. 187.

${ }^{51}$ CARMO, José Vicente do. op. cit., p. 153-154.
} 
pode vir de um conhecimento exclusivamente natural que excluísse uma profissão de fé, pois a salvação é um dom sobrenatural. É uma doutrina herética e contrária a fé aquela que diz "que sem a fé pode salvar-se algum homem" ${ }^{52}$ A fé é necessária e imprescindível. "A fé é antecipação das coisas que há que esperar e prova das que não se vêm". ${ }^{53}$ Sem a fé, não há como acreditar naquilo que não é evidente racionalmente. "Ninguém pode salvar-se sem a fé explícita em Cristo". ${ }^{54}$ Ninguém vai ao Pai a não ser através de Cristo, único caminho e porta exclusiva para entrar na vida eterna. "Se sem conhecimento de Cristo pode haver salvação ou justificação, então não vale a pena pregar a Cristo e é inútil enviar os apóstolos ao mundo inteiro". ${ }^{55}$ Anunciar a Cristo é necessário para que os homens alcancem a salvação. A fé em Cristo é necessária a todos. ${ }^{56}$ Por isso, é necessário pregar o Evangelho para que ouvindo creiam e sejam salvos.

\subsection{Universalismo salvífico cristocêntrico}

A grande questão que se impõe com relação ao contexto do Novo Mundo é como entender a universalidade da graça e da salvação estando esses povos privados do conhecimento de Cristo? O tema da justificação move os tempos de Reforma e Contra-Reforma. O séc. XVI tem uma profunda preocupação existencial em torno do tema da salvação. Como tudo isso pode fazer sentido para essas pessoas que nunca ouviram falar de Cristo? Acosta tem como paradigma uma história da salvação

52 ACOSTA, José de. op. cit., p. 191.

${ }^{53}$ Ibid., p. 191.

${ }^{54}$ Ibid., p. 193.

55 Ibid., p. 193.

56 "O conteúdo da fé precisava ser explícito para os catequizandos. Por isso, Acosta valorizava a memorização da fé. A missão fundamental dos missionários era o anúncio de Jesus Cristo salvador. [...] A fé supõe o conhecimento de Cristo, que comunica a salvação. A tarefa primordial dos missionários é, portanto, anunciá-lo como salvador, dado não existir salvação fora desse nome. Embora os índios tivessem recebido esse anúncio, o desconhecimento do nome de Jesus e de sua doutrina tinha causado indignação em Acosta. A catequese não os havia levado à descoberta de Jesus Cristo salvador e comunicador da vida eterna. Nosso autor acentuava então a fé explícita. [...] Os missionários, que anunciavam Jesus Cristo, deviam levar os índios a compreendê-lo explicitamente. Acosta fundamentava-se na pregação de São Paulo, que afirma a necessidade do discernimento e conhecimento daquilo que se crê (cf. $R m$ 10,1-19). Somente podem ser justificados os que conhecem a Cristo. A lei natural não era causa de salvação. Todos estavam obrigados a crer em Jesus Cristo para se salvarem, sobretudo depois do anúncio do Evangelho. A salvação não seria possível fora da Igreja." (CARMO, José Vicente do. op. cit., p. 160-161). 
centrada e manifestada de maneira definitiva em Cristo. Acosta não leva em consideração as histórias da salvação das religiões, para ele existe apenas uma história da salvação para a qual todas as expectativas convergem. Há um universalismo cristocêntrico.

José de Acosta compreende a missão como anúncio das verdades da fé, proclamadas pela Igreja, mas desvinculadas dos valores culturais autóctones. Os outros não são sujeitos da missão, mas povos sem lei e religião. O Espírito Santo, presente e atuante na história e protagonista da missão, fica ausente da cultura e religião dos povos indígenas. A evangelização é uma invasão da história e cultura dominantes sobre a história e cultura dos dominados. ${ }^{57}$

Dos que nunca ouviram falar sobre Cristo, ainda se condenam pelos seus crimes e não por ignorar o Evangelho. Antes de querer estabelecer a própria justiça, é preciso sujeitar-se à justiça de Deus. "Depois de promulgada a lei do Evangelho, nunca e em nenhum lugar podem bastar os antigos sacramentos". ${ }^{58}$ Depois do Evangelho ser pregado e já estar conhecido, não há razão suficiente para afirmar que aos adultos basta apenas o conhecimento da lei natural para salvarem-se. Os que não ouviram falar de Cristo são escusados do pecado de infidelidade, porém, estarão privados da graça da justificação de outros pecados, sendo por esses condenados com razão. A doutrina agostiniana afirma que "o conhecimento de Cristo é tão necessário para a salvação, que ainda aos que se salvaram antes dos tempos do Evangelho assegura que não lhes sucedeu este bem sem a revelação do único mediador entre Deus e os homens, Jesus Cristo". ${ }^{59}$ Os que se salvaram, foi sob a mediação de Cristo, graças à providência de Deus.

Antes do Evangelho, bastava a fé implícita em Cristo, dizem alguns autores mais moderados. "Uma vez revelada a fé, cesse de estar aberta para ninguém a porta da vida se não é através de um conhecimento revelado e expresso de Cristo. Todos os escritores, tanto antigos e novos, mantêm essa tese", ${ }^{60}$ a não ser alguns poucos que não se apóiam na autoridade da tradição, baseando-se apenas em opiniões pessoais. Para a justificação e para a salvação definitiva, é necessário o conhecimento

\footnotetext{
57 Ibid., p. 206.

58 ACOSTA, José de. op. cit., p. 197.

${ }^{59}$ Ibid., p. 199.

${ }^{60}$ Ibid., p. 201.
} 
do Evangelho, depois que este foi promulgado ao mundo. "Só a lei da fé justifica. É dizer, não há nenhum outro princípio de salvação, à margem da fé em Jesus Cristo" "61 A partir do anúncio do Evangelho ao mundo inteiro, iniciou-se, de modo concreto, a necessidade da fé explícita em Cristo para a justificação.

Segundo Acosta, seguindo a lógica da economia salvífica, não há razões suficientes para atribuir a alguém o perdão de seus pecados sem o conhecimento de Cristo. "Sem a fé no mistério de Cristo, ninguém pode ser justificado", ${ }^{62}$ assim ensinou Santo Tomás de Aquino e o Concílio de Trento. Mas podemos nos perguntar, como fica a situação daqueles que ainda não tiveram a oportunidade de escutar o Evangelho? Para Acosta, são muitas as opiniões a respeito do tema. Porém, "não há razão para abandonar dogmas certos para seguir opiniões incertas". ${ }^{63}$ Por isso, apesar dos questionamentos, não podemos deixar de ensinar o mistério de Cristo, imaginando que as pessoas possam alcançar a salvação por força própria, sem o auxílio da graça de Deus. Isso seria auto-suficiência humana.

Uma coisa é certa: todos os escritores afirmam que o conhecimento de Cristo é necessário para todos aqueles a quem foi pregada a fé. E mais, todos ensinam expressamente que o preceito de crer explicitamente o mistério de Cristo é divino e se propõe a todos os homens como necessário, e que os que ouviram a fé, não podem salvar-se sem o conhecimento desse mistério. ${ }^{64}$

Acosta postula ser um argumento errôneo aquele que afirma que os índios não precisam crer explicitamente em Cristo, bastando-lhes crer na divindade que premia os bons e castiga os maus. A razão que fundamentaria esse argumento seria que Deus não obriga alguém a fazer algo impossível. No entanto, isso seria negar a capacidade racional dos indígenas, considerando-os inferiores do ponto de vista humano, e seria privar-lhes da promessa divina de salvação, que não faz acepção de raças ou povos, mas que tem uma destinação universal a todo gênero humano. Esse tipo de afirmação miraria nas bases todo o empenho evangelizador junto aos índios.

\footnotetext{
${ }^{61}$ Ibid., p. 203.

62 Ibid., p. 205.

${ }^{63}$ Ibid., p. 209.

${ }^{64}$ Ibid., p. 211.
} 


\section{Conclusão}

Para Acosta, é uma grande impiedade ir contra o mandamento do Senhor que diz: "ide por todo o mundo, proclamai o Evangelho a toda criatura. Aquele que crer e for batizado será salvo" (Mc 16,15-16). Todo cristão precisa professar essa certeza, e a Igreja, enquanto comunidade de fé, não tem outra missão do que aquela de tornar Cristo conhecido e amado por todos. "Se o índio não conhece a Cristo, não pode conhecer o mistério da Igreja", ${ }^{65} \mathrm{e}$ vice-versa. A Igreja não pode deixar de anunciar Cristo aos índios, do contrário, perderá a sua razão de ser.

O mistério de Cristo é possível de ser crido por todos. "Ninguém é tão inapto que não possa pensar de algum modo em Deus e no homem. É possível, pois, ensinar-lhe que Deus se fez homem, e esse homem é Cristo", ${ }^{66}$ que se encarnou e entregou a sua vida para livrar-nos de nossos pecados, para que conseguíssemos a vida eterna. Qualquer pessoa é capaz de compreender Cristo como nosso único salvador. Há algo fundamental que nós devemos confessar: o Mistério Pascal de Cristo que quer se comunicar a nós. Cristo é inequívoco, não pode ser confundido com outras coisas ou com outras noções de divindades de outras culturas e religiões. Ocorre uma desambiguação pelo conhecimento explícito de Cristo.

Mesmo que haja muitas pessoas que são surdas para o Evangelho, e que ninguém pode conhecer perfeitamente o mistério de Cristo, ainda assim, Cristo é uma opção inegociável. A teologia da missão de Acosta é essencialmente cristológica, de teor impreterivelmente catequético. É preciso conhecer e confessar a fé conforme o símbolo da fé e receber o batismo. Os incapazes são escusados de cumprir determinações, mas com desejo sincero e propósito autêntico, fazendo o possível, ninguém é excluído do Reino de Deus.

Em Cristo está todo o mérito da salvação e Cristo o dá a todos os seres humanos. Tudo o que era necessário para a culpa ser expiada foi feito. O cumprimento da satisfação dessa culpa incomensurável foi realizado, o ser humano não pode acrescentar nada a isso. Cur Deus homo? Essa é a linguagem da satisfação aplicada à cristologia por Santo Anselmo. Objetivamente todos foram salvos, porém subjetivamente é preciso aceitar essa salvação. É impossível que Cristo aconteça no

\footnotetext{
${ }^{65}$ Ibid., p. 217.

${ }^{66}$ Ibid., p. 219.
} 
indivíduo sem que este o conheça e aceite. Cristo é o mediador, o eixo da salvação. Acosta interpreta isso em sentido cognitivo: é preciso conhecer para convencer-se, aceitar, amar e viver a fé.

Acosta é um radical: o conhecimento de Cristo é necessário. Para Acosta é preciso falar explicitamente da mediação de Cristo. É inegociável e indissolúvel esse conteúdo. Cristo é o centro da história da salvação, é o único e necessário mediador. As narrativas precisam ser englobadas e interpretadas pelo evento Cristo. Na filosofia da religião de Acosta todas as narrativas se encaminham para Cristo.

\section{Referências}

ACOSTA, Jose de. De procuranda indorum salute. In: Corpus Hispanorum de Pace. Vol. 23. Madrid: Consejo Superior de Investigaciones Científicas, 1987. (Pacificacion y Colonizacion).

. De procuranda indorum salute. In: Corpus Hispanorum de Pace. Vol. 24. Madrid: Consejo Superior de Investigaciones Científicas, 1987. (Pacificacion y Colonizacion).

BÍBLIA. Português. A Bíblia de Jerusalém. Nova edição rev. e ampl. São Paulo: Paulus, 2002.

CARMO, José Vicente do. A proposta de evangelização de José de Acosta: repercussões para a missão hoje. Santa Maria: Biblos, 2003.

GUTIÉRREZ, Gustavo. Em busca dos pobres de Jesus Cristo: o pensamento de Bartolomeu de Las Casas. Trad. Sérgio José Schirato. São Paulo: Paulus, 1995.

LAS CASAS, Bartolomeu de. Único modo de atrair todos os povos à verdadeira religião. Trad. Noelia Gigli; Hélio Lucas. São Paulo: Paulus, 2005. (Frei Bartolomeu de Las Casas).

ZILLES, Urbano. Religiões: crenças e crendices. 4. ed. Porto Alegre: Edipucrs, 2012. 